\title{
PROBLEMS IN TRADITIONAL LANDFILLING AND PROPOSALS FOR SOLUTIONS BASED ON SUSTAINABILITY
}

\author{
Valentina Grossule ${ }^{1, \star}$ and Rainer Stegmann ${ }^{2}$
}

${ }^{1}$ DICEA, Department of Civil, Architectural and Environmental Engineering, University of Padova, Via Marzolo 9, 35131 Padova, Italy

${ }^{2}$ Hamburg University of Technology, Institute of Environmental Technology and Energy Economics, Harburger Schlossstrasse 36 - 21079 Hamburg, Germany

Article Info:

Received:

9 August 2020

Revised:

19 August 2020

Accepted:

24 August 2020

Available online:

27 August 2020

Keywords:

Sustainable landfilling

Landfill issues

Final storage quality

Multi-barrier concept

\begin{abstract}
In recent years, the Circular Economy has become the key lynchpin underlying the waste management system. However, the emphasis placed on recycling has led, on one hand, to an underestimation of the critical issues that are currently emerging so dramatically (i.e. limited recyclability of materials, instability of markets for secondary raw materials, and accumulation of contaminants present in the recycled materials), whilst on the other to neglect the inescapable role of landfill in waste management. In many cases, landfills are seen as a simple and economical means of disposing of waste, and from a political, legislative and technical viewpoint they are frequently denied the attention devoted to other engineering works, lacking adequate financial investment to cover the costs required to ensure a sustainable landfill system. Landfill should be designed and constructed in line with the principle of environmental sustainability, by adopting technical measures aimed at guaranteeing waste stability and immobilisation of contaminants over a period of less than one generation and ensuring a Final Storage Quality in equilibrium with the environment. This article summarises the concept of sustainable landfilling, identifies the technical strategies that characterise this system, describes the critical issues frequently encountered after decades of operation and proposes a series of solutions aimed to control long-term behavior.
\end{abstract}

\section{INTRODUCTION}

In recent years, the Circular Economy has become the key lynchpin underlying the waste management system. This has led to an increased focus on the role of recycling, viewed as a definitive solution for waste management, and to landfill being deemed an obsolete and potentially redundant system.

Recycling however is by no means a perfect system (Cossu et al., 2020b):

- not all materials can be recycled and recyclable products cannot be recycled endlessly;

- contaminants contained in the products tend to accumulate in the recycled materials and residues;

- even when materials are recycled waste will be produced;

- the system relies on the ongoing availability of the market for secondary raw materials and the recycled products obtained, whilst failing to account for instability factors (generalised economic crises, fall in price of specific primary materials, political or social crises, border closures, natural calamities, health emergencies, etc. )
Indeed, no type of waste management system can disregard a balanced use and integration of different methods of treatment and disposal, each suited to a specific field of application.

International data, routinely communicated, relating to the quantities and percentages of wastes, which, downstream of collection, are forwarded to the main treatment and management options (recycling, thermal treatment and landfilling), typically fail to include the disposal flows of treated waste. This oversight masks the effective use of both landfills and incineration. Cossu et al. (2020b) estimated the actual status quo on an international level by considering final waste disposal, which is achieved in term of end-products for recycling, in term of gasification for thermal treatment and in term of permanent deposit for landfilling. Based on this study the actual amount of waste (combustion and recycling residues) going to landfill is much higher (more than $20 \%$ ) than officially declared.

In particular, landfill constitutes a necessary and irreplaceable system with which to close the material loop in a Circular Economy, providing, in line with the Back to Earth concept, a sink for all those substances and materials that 
would otherwise remain dispersed in the biosphere, thus adding to a diffuse environmental pollution (Cossu, 2016).

The general tendency to strive to "conceal" the unavoidable evidence of a landfill whilst failing to pay sufficient attention to the associated political and legislative requirements has raised a series of critical issues:

- In many cases, landfills are seen as a simple and economical means of disposing of waste, denoted by a frequent lack of technical attention devoted to other engineering works, and a paucity of financial investment required to cover the costs of ensuring a sustainable landfill system.

- The design and operation of a landfill is generally perceived as a simple task, although, in reality, a high degree of awareness, knowledge and experience are mandatory in order to avoid mistakes, which might produce serious consequences in terms of environmental impact and remediation costs (Cossu and Stegmann, 2019).

- The potential impact of landfills remains virtually unchanged due to not having been designed as sustainable systems.

- General populations are frequently fiercely opposed to the development of new landfills.

- As a consequence of anti-landfill or incinerator campaigns, large quantities of wastes are often shipped abroad. A significant example of this is represented by Slovenia in which, although classified as one of the countries featuring a lower use of landfills and high rates of recycling, the waste management system is based largely on the exportation of waste, with the Slovenian statistical office reporting the exportation of 1 million tons of waste out of a total of 6 million tons generated (Republic of Slovenia, Statistical office, 2017).

\section{SUSTAINABLE LANDFILLING}

Following the Rio de Janeiro Conference (1992) and setting up of the Kyoto Protocol (1997), the concept of environmental sustainability has produced a marked change internationally in the strategies applied to protect the environment. However, to date no legislation relating to landfills has contained any mention of the concept of environmental sustainability.

The Back to Earth concept should be achieved by securing, within the time frame of one-generation, a final storage quality of the landfill in equilibrium with the environment. Accordingly, the landfill should be designed and developed in line with the principle of environmental sustainability, adopting all measures required in order to guarantee waste stability and immobilisation of contaminants in a time frame of less than one generation and ensuring the reaching of an equilibrium with the environment (Heimovaara et al., 2014).

\subsection{Barriers}

Potential waste contaminants are essentially present in either a mobilizable or non-mobilizable form. The mobilizable fractions contained in landfilled wastes and exposed to the atmosphere are transformed and pass from one phase to another in line with their characteristics of degradability and leachability. Following these transformations, the mobilised substances accumulate in the emissions generated (leachate and gas), potential environmental pollutants. Controlling of emissions and risk of contamination in both the short and the long term, may be achieved through application of the multibarrier concept (Cossu, 2018), using a series of systems (barriers) that impinge on the following:

\section{- Quantity of deposited wastes \\ - Quality of deposited wastes \\ Emission control}

Barriers suitable for use, graphically depicted in Figure 1, are described in Table 1, identifying the feature affected and the objectives pursued.

Pre-treatments, and in-situ treatments in particular, are essential measures with which to achieve the aims of environmental sustainability, and the choice of measures used and efficacy of the same should be specifically linked to the type and characteristics of the wastes, i.e. biological degradability, calorific potential and leachability of contaminants.

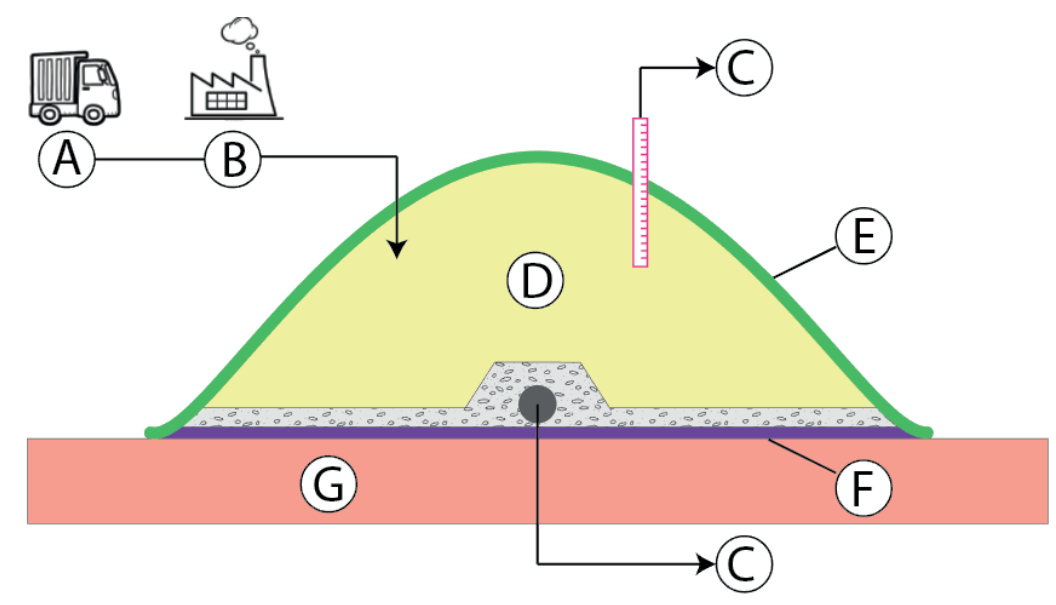

FIGURE 1: Schematic illustration of the multibarrier concept. A, Waste minimization; B, Pre-treatment; C, Biogas and leachate collection and treatment; D, In situ treatment; E, Top cover; F, Lining; G, Siting and morphology. (modified from Cossu et al., 2020c). 
TABLE 1: Barriers, features affected with a view to sustainability and objectives.

\begin{tabular}{|c|c|c|c|}
\hline & Barrier & Features affected & Aim \\
\hline A & Waste avoidance and minimisation & Waste quantity & To minimize waste landfilling \\
\hline B & Pre-treatment & Waste quality & $\begin{array}{l}\text { To minimize the emission potential of wastes prior to } \\
\text { landfilling }\end{array}$ \\
\hline C & Biogas and leachate collection & Emission control & $\begin{array}{l}\text { To maximize biogas and leachate collection and tre- } \\
\text { atment by removing contaminants from the landfill }\end{array}$ \\
\hline $\mathrm{D}$ & In situ treatment & Waste quality & $\begin{array}{l}\text { To minimize the emission potential of wastes subsequent } \\
\text { to deposition in the landfill }\end{array}$ \\
\hline $\mathrm{E}$ & Top cover & Waste quality, Emission control & $\begin{array}{l}\text { To regulate water ingress on the basis of specific pro- } \\
\text { cess requirements. } \\
\text { To implement cultivation layer and/or gas emission miti- } \\
\text { gation systems }\end{array}$ \\
\hline $\mathrm{F}$ & Lining & Emission control & To minimize the uncontrolled dispersion of contaminants \\
\hline G & $\begin{array}{l}\text { Environmental barrier (Siting and morpho- } \\
\text { logy) }\end{array}$ & Emission and mechanical stability control & $\begin{array}{l}\text { To exploit the self-depuration capacity of the envi- } \\
\text { ronment to mitigate potential uncontrolled emissions. } \\
\text { To ensure mechanical stability of the landfill }\end{array}$ \\
\hline
\end{tabular}

\subsection{Pre-treatment}

The objective of any form of treatment to be applied to wastes forwarded to final sustainable disposal should be that of removing, transforming or immobilising potential contaminants into a stable form. This aim may be achieved through the combination of a series of processes and unit operations, as described in Table 2, some of which intended to prepare the material for stabilisation (Physical treatment). The choice of intervention and expected efficacy will be linked to type and characteristics of the waste (putrescibility, calorific value, leachability of contaminants, etc.).

In the case of municipal solid waste (MSW), biological pre-treatment as well as thermal pre-treatment are practised; both further to reduce the organic content to low values (biological waste stabilisation), allow a significant volume reduction, particularly with thermal treatment.

As a general rule, the biological pre-treatment of MSW is always combined with mechanical processes to afford the so-called Mechanical Biological Treatment (MBT), the aim of which is to stabilise undifferentiated wastes prior to landfilling (Stegmann, 2018). During mechanical pre-treatment the high calorific value fraction of MSW is separated mainly by sieving. Following additional mechanical treatment, the remaining fraction will be biologically stabilised prior to landfilling.

The main effects produced by MBT on wastes to be landfilled are as follows (Leikam and Stegmann, 1999; Stegmann and Heyer, 2001, 2002):

- Weight reduction (40-70\%).

- Reduction and homogenisation of granulometry.

- Increase in specific surface area with consequent potential improvement of biological stabilisation process within the landfill.

- Enhancing compaction in the landfill.

- Reduced settling rates.

- Increased instability due to reduction in granulometry and removal of elements resistant to traction (i.e. fibres and plastics) by means of mechanical treatment, to achieve maximum gradients of 1:3 on slopes.

- Reduction of hydraulic conductivity with potential increase of neutral pressure and consequent risk of mecha- nical instability.

- More than $90 \%$ reduction in the emission potential of the wastes with decreased COD and total nitrogen in leachate and lower stability indexes $\left(\mathrm{R}_{14}, \mathrm{GP}_{21}\right)$.

Amongst the different forms of thermal treatment (combustion, pyrolysis, gasification, etc.), combustion (or incineration) is the most widely process applied for municipal solid wastes. The residues of thermal treatment account for $10 \%$ of the initial volume and $25-30 \%$ of the initial weight, including bottom ashes, grate siftings, boiler and economizer ashes, fly ashes, and Air Pollution Control (APC) residues. The various types of residue are characterised by a diversity of physical, chemical and mineralogical properties with a markedly differentiated composition. In particular, residues such as fly ashes and residues from flue-gas treatment feature a higher concentration of metals (Sabbas et al., 2003) and toxic trace organics (e.g. halogenated hydrocarbons).

Combustion residues may be landfilled or recycled and used as road construction material meeting specific conditions (e.g. beneath an impermeable asphalt layer) or in cement production. Whichever form of final disposal is applied, the potential environmental impacts of incineration residues are generally associated with emission of dust, gas and leachate, with the latter representing the major source of concern. Pre-treatment comprising the inertisation or leaching of residues will facilitate the reduction of contaminant load or modify leachability.

If thermally or mechanical-biologically pre-treated waste is landfilled the emission potential will be significantly reduced, although emission control will still be required (Heyer, et. al, 2013).

In the opinion of the authors, a status similar to that of an MBT landfill may be achieved by implementing the separate collection of kitchen and yard waste and landfilling residual waste in a bio-reactor landfill with subsequent in-situ aeration. Of course, this process needs significantly longer time to reach the emission values expected from MBT landfills.

The physicochemical treatment of waste washing (or elution) is aimed at separating wastes to facilitate the re- 
TABLE 2: Classification and description of unit operations applied in waste pre-treatment or in-situ treatment according to process type.

\begin{tabular}{|c|c|c|c|}
\hline & Process & Unit operations & Aim \\
\hline \multirow{5}{*}{ Pre-treatments } & Physical & $\begin{array}{l}\text { - Shredding } \\
\text { - Size separation (Sieving) }\end{array}$ & - Pre-treatment, recovery of RDF \\
\hline & Biological & $\begin{array}{l}\text { - Anaerobic digestion } \\
\text { - Aerobic stabilisation } \\
\text { - Composting }\end{array}$ & $\begin{array}{l}\text { - Biological stabilisation } \\
\text { Resource recovery (methane, hydrogen, } \\
\text { compost) }\end{array}$ \\
\hline & Thermal & $\begin{array}{l}\text { - } \text { Combustion } \\
\text { - } \text { Pyrolysis* } \\
\text { - Gasification* } \\
\text { - Thermal inertisation (vitrification, melting, sintering) }\end{array}$ & $\begin{array}{l}\text { - Reduction of waste volume } \\
\text { - } \text { Destroying of organic contaminants } \\
\text { - Recrgy recovery } \\
\text { - Recling of ashes }\end{array}$ \\
\hline & Physical-Chemical & $\begin{array}{l}\text { Washing (with or without chemical agents) of inorganic } \\
\text { waste }\end{array}$ & $\begin{array}{l}\text { - Removal of contaminants } \\
\text { - Reduction of emission potential }\end{array}$ \\
\hline & Chemical - Physical & $\begin{array}{l}\text { Solidification by both inorganic (e.g. Hydraulic binder) and } \\
\text { organic (e.g. Thermoplastic materials) reagents. }\end{array}$ & $\begin{array}{ll}\text { - } & \text { Reducing leachability } \\
\text { - } & \text { Increasing mechanical stabilisation } \\
& \text { Resource recovery (recycling of stabili- }\end{array}$ \\
\hline $\begin{array}{l}\text { In situ treatment } \\
\text { (Bioreactor landfills) }\end{array}$ & Biological & $\begin{array}{l}\text { - Controlled leachate recirculation } \\
\text { - In-situ aeration } \\
\text { - Natural/passive aeration }\end{array}$ & - Biological stabilisation \\
\hline
\end{tabular}

* Mainly applied in Japan or occasionally in other countries for industrial waste

covery of recyclable materials and/or at reducing emission potential of the waste with a view to sustainable disposal (GeoSyntec, 2003). During the washing process, any leachable compounds are transferred from the solid to the liquid phase. In the case of inorganic substances the efficacy of the process depends on a series of factors, including solubility, $\mathrm{pH}$, redox potential, and presence of chlorides and dissolved organic matter.

Another physicochemical treatment method to significantly reduce the leachability of suitable solid wastes with a prevalently inorganic matrix is called inertisation or solidification. The advantage of some of these forms of pre-treatment is represented by the possibility of achieving a higher efficiency compared to that afforded by washing, resulting in some instances in the possibility of recycling the inertised product for use a secondary raw material (Andreola et al., 2017). The main drawback is associated with the need to use additives (binders, reagents, etc.) and/or high amounts of energy resulting in a costly treatment. Often the long- term effects of the solidified waste are not well known. In case of elution high amounts of water are used, sometimes with the addition of chemicals (control $\mathrm{pH}$, etc.), and the eluted sludge like compounds have to be further treated or landfilled.

\subsection{In situ treatment (Landfill Bioreactors)}

Due to evident economical and technical issues, waste pre-treatment prior to landfilling may fail to result in a sufficient stabilisation of wastes - either in terms of biological stability or in terms of stability against leaching - to guarantee an adequate final storage quality. This may still be achieved by means of in-situ treatments.

These measures may be implemented either during the operational phase of the landfill or during the post-management phase and should be selected, dimensioned and described in detail during the design stage.

Potential in-situ treatments may comprise one or more of the following options (Table 2):

- Controlled leachate recirculation

\section{- Natural aeration \\ Forced aeration}

Controlled water infiltration (in general treated or untreated leachate recirculation) may promote the biodegradation processes due to an increase in moisture content of the waste and water flux. This approach makes only sense when the water content of the waste is insufficient to promote biological processes. High addition of water or leachate may result in water ponding, which may reduce the stability of refuse mounds. Moreover, the option of providing for the sole leaching of landfilled waste by means of addition of high water volumes for the purpose of releasing a landfill from aftercare after a relatively short period (comparable to in-situ aeration) is, in the opinion of the authors, neither practical nor feasible. The findings of the international research project EVAPASSOLD demonstrated that to reduce the emission potential of a landfill to environmentally acceptable concentrations, water volumes corresponding to approx. 3-5-fold the deposited waste volume (liquid/solid factor 3-5) will need to migrate through the waste, which may not prove to be a feasible option (Allgaier and Stegmann and Heyer, 2002).

Landfills adopting the different unit operations either individually or in combination are typically recognized as landfill bioreactors, which are categorized into the following types:

- Anaerobic landfill, featuring - where appropriate - a controlled recirculation of leachate.

- Aerated landfill, comprising the injection of air at low pressure through vertical or horizontal wells into the landfill body and simultaneous extraction of the corresponding amount of gas, which will require treatment prior to release into the environment. In view of the authors in-situ aeration shall only be applied to landfills with a low content of organic degradable matter (Ritzkowski, et al., 2006, Ritzkowski, et. al, 2013, Hupe and Stegmann, 2013).

- Semi-aerobic landfill, which thanks to the specific 
construction of a system of chimneys and pipelines, is characterised by a natural convective circulation of air obtained through the difference in temperature between the waste mass and the external environment (Matsufuji et al., 2018).

Hybrid landfill, with a sequence/alternation of aerobic and anaerobic conditions (Cossu and Grossule, 2018). This concept has been mainly applied in lab studies and relevance in full scale application is lacking.

Achievement of the aims of environmental sustainability is guaranteed by the multiple benefits afforded by in-situ treatments, including reduced time frame for interventions and lower post-management costs, shorter duration of environmental responsibility for the landfill management, accelerated reduction of emission potential (due to an increased degradation and leaching) and mechanical stabilisation of the waste mass. On the other hand, the main disadvantages may include higher costs, higher complexity of construction, management and operation.

Specific advantages and disadvantages of each landfill bioreactor category are summarized in Table 3 .

In the opinion of the authors the only method, by which an enhanced reduction of the residual emission potential of a closed landfill can be achieved, is the in-situ-aeration. In many cases the existing landfill gas extraction system with some additions can be used. The results gained from actual full- scale aerobic in situ stabilization landfill projects show an enhanced biological stabilization with accelerated reduction of settlements (Ritzkowski et. al., 2006). This process may be supported by a controlled water infiltration (Stegmann, 2017a).

\subsection{Final storage quality and closure of the aftercare}

A landfill may be deemed sustainable if - following the integration of a series of barriers - the emission potential of the landfilled waste and the quality of emissions reached is such as to not produce any non acceptable effect on the environment. This status should be reached over the time frame of one generation.

This quality is typically defined as final storage quali- ty (FSQ), according to which, on terminating management of a sustainable landfill, the remaining uncontrolled contaminant load will not necessarily correspond to zero. It is mandatory however that residual pollutants should be compatible with the surrounding environment and guarantee an equilibrium that does not perturb the quality of the environment, whilst exploiting its ability to self-depurate.

The design of a sustainable landfill therefore should be based on the ability to achieve the FSQ, subsequent to which the main aftercare phase is terminated, which may release the landfill operators from any form of environmental liability. Anyway, in the opinion of the authors, a certain monitoring and maintenance of a landfill will be always necessary for a non-predictable time.

The question as to when a landfill can be released from aftercare is difficult to answer. Some studies have defined FSQ by proposing limit values for landfill emissions (leachate quality and load, gas production, etc.). In Germany, several studies put forward FSQ values for use by the German Federal Environment Ministry (Stegmann, et al., 2006, Stegmann, et al., 2003, Stegmann, et al., 2011), whilst in Italy FSQ values were proposed by a national technical committee (CTD) in 2006 and implemented in the official regulation for sustainable landfilling of the Lombardia Region (Deliberation of the Regional Council 2461/14; Cossu et al., 2020d).

The combination of pre-treatments and in-situ treatment should be envisaged with an aim to pursuing the FSQ objective, exploiting their complementarity to reduce the emission potential of wastes $\left(S_{t}\right)$, as graphically represented in Figure 2.

It is evident that financial provisions to be ensured over a defined time frame (in Italy, 30 years) are not sufficient to guarantee Final Storage Quality (FSQ) of the landfill. If no technical interventions are implemented to achieve the FSQ, on termination of the financial provisions, the place of what should simply be a closed landfill will be taken by a contaminated site with unsustainably high costs of recovery.

Aftercare costs are frequently overlooked or not given due consideration in budget planning. For a long period,

TABLE 3: Categorisation of different landfill bioreactors, identifying the characteristic unit operation and specific advantages and disadvantages (Cossu,and Grossule, 2018; Grossule et al., 2018; Grossule and Lavagnolo, 2019; Ritzkowski and Stegmann, 2003, 2007).

\begin{tabular}{|c|c|c|c|}
\hline Bioreactor type & Unit operations & Advantages & Disadvantages \\
\hline Anaerobic & $\begin{array}{l}\text { Leachate recircu- } \\
\text { lation* }\end{array}$ & $\begin{array}{l}\text { - Improvement of biodegradation processes by control- } \\
\text { ling water content and flux } \\
\text { - Improvement of leachate quality } \\
\text { Biogas generation enhancement, concentrated to a } \\
\text { shorter period of time } \\
\text { Better removal of soluble compounds }{ }^{\star \star} \text {, including am- } \\
\text { monia under anaerobic conditions and organic acids } \\
\text { from the acidic and acetogenic phase, reducing possi- } \\
\text { ble inhibition of fermentation phase }\end{array}$ & $\begin{array}{l}\text { - Costs of recirculation } \\
\text { - Potential of leachate ponding }\end{array}$ \\
\hline Aerobic & Forced aeration & $\begin{array}{l}\text { - Acceleration of biodegradation kinetics } \\
\text { - } \text { Better waste settling } \\
\text { - } \text { Reduction of uncontrolled methane dispersion } \\
\text { - Nemoval }\end{array}$ & Energy demand \\
\hline Semi-aerobic & Natural aeration & $\begin{array}{l}\text { - Acceleration of biodegradation kinetics } \\
\text { - } \quad \text { Litrogen removal } \\
\text { - Low system }\end{array}$ & $\begin{array}{l}\text { Careful management and operation for opti- } \\
\text { mal system performance }\end{array}$ \\
\hline
\end{tabular}

* Leachate recirculation, not applicable at high water content of waste mass, **/t has to be distinguished between raw or treated leachate recirculation. 


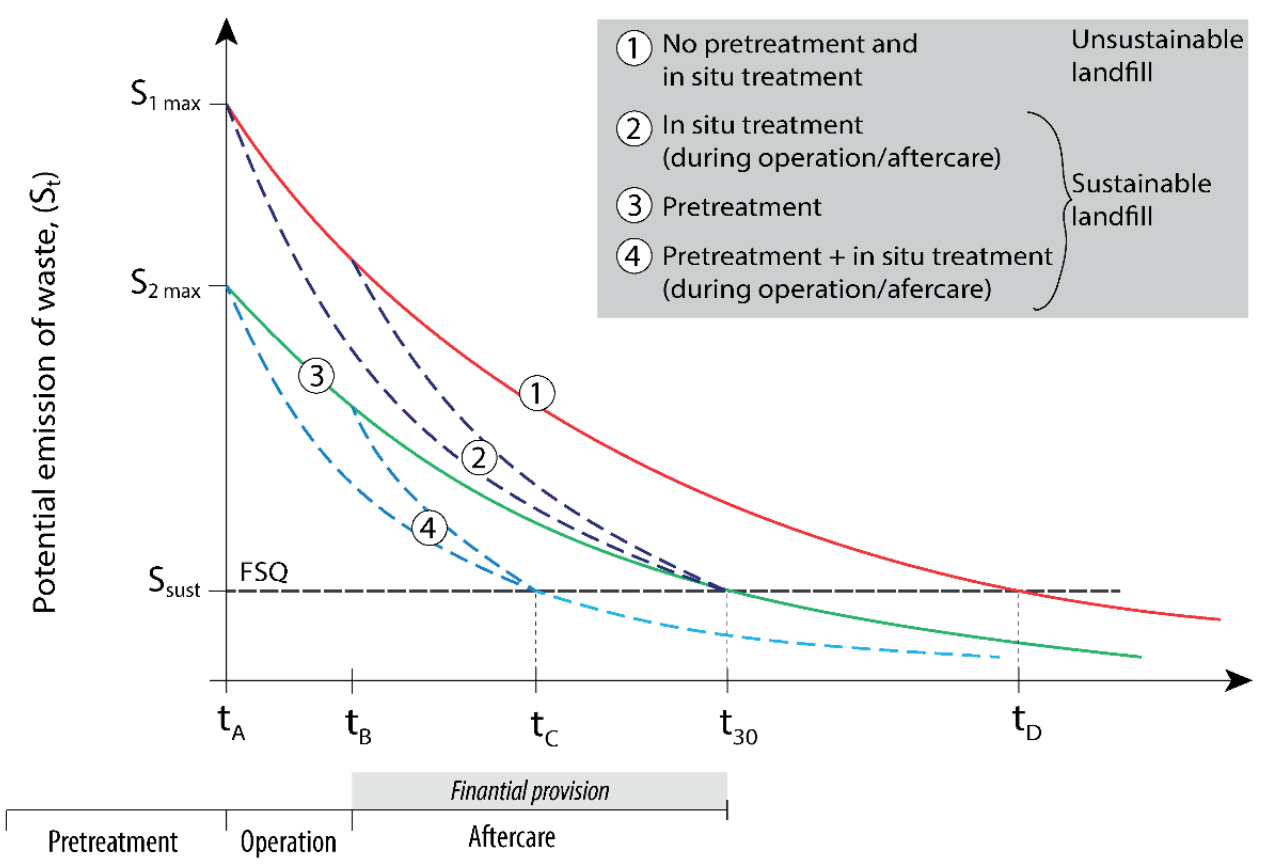

FIGURE 2: Time trend of the emission potential for release of contaminants from a landfill. FSQ= Final Storage Quality, according to which the emission potential reaches a value of $S_{\text {sust }}$ in equilibrium with the environment; $t_{A^{\prime}}$ peak in emission potential during landfill operations; $t_{B^{\prime}}$ Closure of landfill operations and commencement of aftercare; $t_{c}$, Anticipated achievement of FSQ; $t_{30}$, Sustainability target and termination of financial provisions; $\mathrm{t}_{\mathrm{D}^{\prime}}$ FSQ beyond the 30-year threshold (unsustainable landfill). (Modified from Cossu et al., 2020c).

the unrealistic opinion was held that 30 years after closure landfills no longer require special care and - if operated by the private sector - may be returned to the communities. Experience however has clearly demonstrated that non-sustainable landfill aftercare will be required for numerous decades and, in the case of large landfills, possibly even a century or more. This is also the case for landfills with a low emission potential (Heyer, 2018).

Potential combinations of pre-treatments and in-situ treatments suitable for reaching the status of a sustaina- ble MSW landfill in due time are graphically displayed in Figure 3.

\section{TYPICAL TECHNICAL AND REGULATIVE PROBLEMS ASSOCIATED WITH TRADITIO- NAL NON-SUSTAINABLE LANDFILLS AND SOLUTIONS}

Landfill technologies implemented worldwide vary considerably. In low-income countries often open dumps are

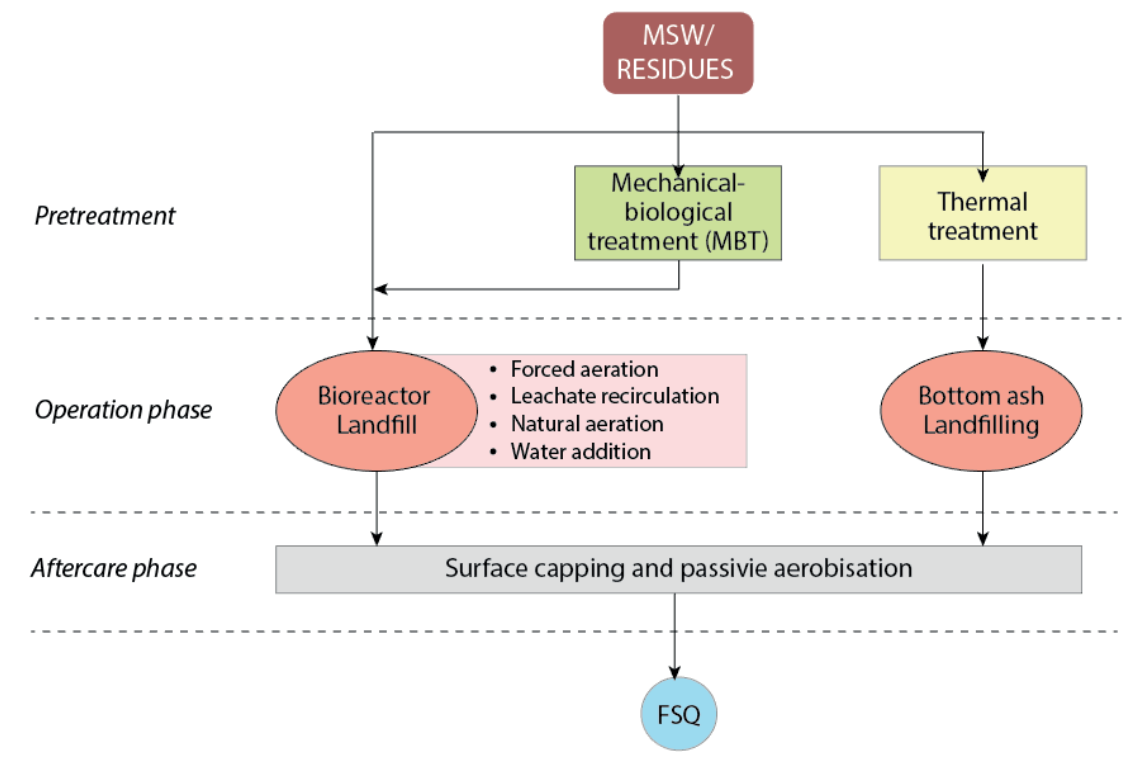

FIGURE 3: Scheme illustrating the possible combinations of pre-treatment and in-situ treatment options for municipal solid waste (MSW) with a view to ensuring landfill sustainability and achievement of FSQ. 
in use in which all kinds of wastes are disposed. This form of disposal implies a total lack of emission control, absence of waste compaction, sites selected with no regard to reducing environmental impact and very steep slopes. Waste dumping results in a range of problems, including: mechanical instability, fires, littering, odours, uncontrolled leachate, gas and toxic fumes emissions. On the other hand, the transfer of modern landfill systems, developed in industrialized countries, to tropical countries should be carefully managed to avoid failures, whilst bearing in mind the specific local situation (different waste composition, high temperatures and strong rainfall periods) (Lavagnolo and Grossule, 2018).

Conversely, even in industrialised countries, although landfills have undergone marked technical advances, a series of problematic issues raise. These are linked largely to reliance on physical containment measures alone (lining and leachate and gas extraction systems), despite the finite duration of this form of containment. Increasingly, drainage systems become clogged, drainpipes collapse, gas extraction wells lose functionality, and plastic membranes fail to maintain their initial quality. Moreover, the problem of longterm landfill emissions remains inadequately addressed (Heyer, et.al. 2005). Landfills will continue to require regular maintenance and repairs (depreciation period for buildings approx.30 years) but the duration of ongoing aftercare remains unclear and commonly, insufficient funds are earmarked for aftercare costs.

The lack of an appropriate landfill design project corresponding to the principles of sustainability based on use of the above-mentioned technical strategies, has resulted in a series of critical aspects highlighting both regulatory and design inadequacies. Typical technical issues in modern non-sustainable landfills are listed in Table 4 and classified according to the barriers used (previously illustrated in Figure 1, Table 1). In particular, the following paragraphs describe in detail these technical issues and provide potential technical solutions.

\subsection{Waste minimisation}

The minimisation of waste forwarded to landfill is one of the key European strategies aimed at "preventing det-

TABLE 4: Typical technical problems in modern non-sustainable landfills.

\begin{tabular}{|c|c|c|c|}
\hline Barriers & Critical element & Consequences & Environmental impact \\
\hline A & $\begin{array}{l}\text { Waste minimisation as the only strategy to } \\
\text { address impacts from landfills }\end{array}$ & $\begin{array}{l}\text { Absence of a legislative and technical upgrade } \\
\text { of traditional landfill towards the sustainability } \\
\text { concept }\end{array}$ & Environmental unsustainability \\
\hline $\mathrm{B}$ & $\begin{array}{l}\text { Pre-treatment is not designed to foster } \\
\text { achievement of FSQ }\end{array}$ & Long-term environmental impact & $\begin{array}{l}\text { Environmental sustainability may be reached } \\
\text { after very long times; many decades to century }\end{array}$ \\
\hline C & $\begin{array}{l}\text { Legal ban of acceptance of high calorific } \\
\text { value wastes }\end{array}$ & $\begin{array}{l}\text { Recycled high calorific value wastes have to } \\
\text { be thermal treated }\end{array}$ & $\begin{array}{l}\text { "carbon sink" only for humic like substances } \\
\text { as a result of biological treatment }\end{array}$ \\
\hline C & $\begin{array}{l}\text { Inadequate design of drainage system } \\
\text { including materials }\end{array}$ & $\begin{array}{l}\text { Drainage dysfunction and inefficiencies/high } \\
\text { water table }\end{array}$ & $\begin{array}{l}\text { Increased risk of pollution and mechanical } \\
\text { instability }\end{array}$ \\
\hline C & Use of geotextiles to protect drainage bed & $\begin{array}{l}\text { Premature clogging of drainage system / } \\
\text { Leachate build-up }\end{array}$ & Increased risk of pollution, odours \\
\hline C & $\begin{array}{l}\text { Limited long-term functionality of drainage } \\
\text { system including collection pipes }\end{array}$ & $\begin{array}{l}\text { Drainage dysfunction and pipe rapture /high } \\
\text { water table }\end{array}$ & $\begin{array}{l}\text { Increased risk of pollution, odours, loss of } \\
\text { mechanical stability }\end{array}$ \\
\hline C & Gas wells and pipes & Uncontrolled gas emissions & Environmental unsustainability \\
\hline $\mathrm{D}$ & $\begin{array}{l}\text { Neglect of scientific development relating to } \\
\text { in situ waste stabilisation (in-situ aeration, } \\
\text { leachate recirculation) }\end{array}$ & $\begin{array}{l}\text { Insufficient biological stabilisation and } \\
\text { leaching of contaminants }\end{array}$ & Environmental unsustainability \\
\hline $\mathrm{D}$ & Scarce attention to quality of daily cover & $\begin{array}{l}\text { Reduced permeability of waste mass, } \\
\text { ponding, gas circulation hampered }\end{array}$ & Odours, mechanical instability, dust \\
\hline D & Build-up of high temperatures & $\begin{array}{l}\text { Inhibition of methane generation, deformation } \\
\text { of plastic liners and pipes }\end{array}$ & Increased risk of pollution, risk of fires \\
\hline $\mathrm{D}$ & $\begin{array}{l}\text { Lack of definition of Final storage quality } \\
\text { (FSQ) }\end{array}$ & $\begin{array}{l}\text { Uncertainty when releasing a landfill from } \\
\text { aftercare }\end{array}$ & Uncertainty regarding aftercare period \\
\hline $\mathrm{E}$ & $\begin{array}{l}\text { Landfill top sealing directly after end of } \\
\text { operation }\end{array}$ & $\begin{array}{l}\text { Insufficient water supply, reduced stabilisation, } \\
\text { conservation of emission potential of waste }\end{array}$ & Environmental unsustainability \\
\hline $\mathrm{E}$ & $\begin{array}{l}\text { Scarce concern over potential use of methane- } \\
\text { oxidizing cover }\end{array}$ & Escaping of the dispersed residual biogas & Environmental unsustainability \\
\hline $\mathrm{F}$ & Duration of geomembranes & Rupture, leachate infiltration & Increased risk of pollution \\
\hline $\mathrm{F}$ & Duration of efficiency of clay layers & Leachate infiltration & Increased risk of pollution \\
\hline G & $\begin{array}{l}\text { Scarce consideration of the morphological } \\
\text { features of the landfill }\end{array}$ & $\begin{array}{l}\text { Incongruous insertion into the landscape, } \\
\text { unstable drainage }\end{array}$ & Inconvenience for the population \\
\hline G & $\begin{array}{l}\text { Scarce consideration for landfill siting taking } \\
\text { into account natural capacity for attenuation }\end{array}$ & $\begin{array}{l}\text { Landfill development below the natural } \\
\text { surface levels, even in sensitive areas }\end{array}$ & Increased risk of pollution \\
\hline Other & Height limit for the landfill above ground & $\begin{array}{l}\text { Steep slopes, unsightly appearance, extension } \\
\text { of deposit below natural surface levels }\end{array}$ & $\begin{array}{l}\text { Impact on the landscape, risk of instability, } \\
\text { precarious runoff }\end{array}$ \\
\hline Other & Viewing of the landfill as an economic system & $\begin{array}{l}\text { No investment aimed at strengthening } \\
\text { barriers }\end{array}$ & Environmental unsustainability \\
\hline
\end{tabular}


rimental impacts on human health and the environment" ascribed to landfills (2018/850/EU). However, the Circular Economy is quite far to reach the "Zero Waste" target, and landfill continues to play an unavoidable role in receiving residual wastes within the Circular Economy. Although the quantities of waste forwarded to landfill have decreased significantly, the change in quality and long-term impacts produced have been somewhat overlooked from a regulatory and design viewpoint. In particular, although the amounts of putrescible organic substances have been reduced, little is known with regard to a potential increase in inorganic substances (including heavy metals) and persistent organic substances that tend to accumulate during waste recycling.

With regard to paper for example, a study conducted by Pivnenko et al. (2015) identified 51 hazardous substances (mineral oils, phthalates, phenols, parabens and other groups of chemical compounds) that tend to accumulate during the recycling process. Many of these compounds have been detected at higher concentrations in recycled paper compared to paper produced from the raw material.

\subsection{Pre-treatment}

In the majority of cases, both from a regulatory and design viewpoint, a strategic approach to waste pre-treatment prior to landfilling is lacking. Indeed, although European regulations establish acceptance criteria, these fail to guarantee sustainability and compliance with achievement of a specific final storage quality required for termination of the aftercare period.

The lack of a comprehensive strategic vision relating to waste pre-treatment is highlighted by the classification of landfill based on type of wastes deposited (inert, non-hazardous, hazardous). In the presence of an increased hazardousness, the regulations merely prescribe an increased thickness of physical barriers, failing to implement any significant measures to reduce the potential contaminant load by means of appropriate pre-treatment or in-situ treatment with a view to achieving environmental sustainability.

Lastly, the prohibition of landfilling for wastes with a high stable TOC or calorific value will ineluctably rule out the potential role of landfill as a carbon sink, which would contribute towards reducing the impact on generation of greenhouse gases (Cossu, 2012). The principles established by the EU whereby the landfilling of wastes potentially suited to recycling or other forms of recovery is prohibited, with the exception of wastes for which landfilling is indicated as representing the most effective environmental solution (2018/850/CE). As a compromise the authors support the idea of landfills as an intermediate storage area for high calorific materials as plastic, in case there are no options for material or energy recovery.

\subsection{Biogas and leachate collection}

A series of critical aspects have emerged with regard to leachate drainage.

- Inadequacy of the granular drainage material used (in terms of granulometry, homogeneity, cleanliness, resistance, etc.) may result in clogging of the drainage sy- stem, potentially compounded in the case of leachates having a high biodegradable organic load, due to the formation of bacterial film combined with precipitation of iron and carbonates. In view of the unfeasibility of intervening directly to maintain drainage, it is fundamental that the drainage bed covers the entire bottom of a landfill and is made up of large, homogenously-sized inert material (mainly gravel) in order to provide a large volume and to avoid/reduce clogging. In addition it increases the movement of leachate on the bottom liner (slope towards the drainpipes $>3 \%$ ) towards the drain pipes and facilitates the transfer of potential clogging material through the drainage pipes (the sole inspection point throughout the entire drainage system). Therefore the slots in the drainpipes should be around $1 \mathrm{~cm}$ wide. In order to reduce organic leachate concentrations, the authors recommend waste pre-treatment and installing a layer of up to $\pm 2 \mathrm{~m}$ of composted MSW on top of the gravel layer of the leachate collection system. This composted waste layer will act as an anaerobic filter for the migrating leachate from the upper waste layers (Stegmann, 1995, Lavagnolo, et. al. 2018). In this way, the readily degradable organics are partly anaerobically degraded to biogas. Moreover, the composted MSW layer will also contribute positively towards reducing incrustations in the leachate collection system, as these are strongly associated with the presence of high organic acid concentrations in leachate (Brune et al., 1991). This concept has been successfully implemented in a series of landfills in Germany (Stegmann, 1995). Finally, the use of geotextiles to protect the drainage bed against clogging, frequently prescribed in Italy and other countries by the competent authorities prior to issuing of authorisation, may actually worsen the problem rather than solving it.

- The long-term functionality of the drainage system is naturally subject to degeneration: clogging of the pipes due to incrustations is widely observed, despite the regular inspection and cleaning (by high pressure flushing) of the drainpipes; deformation or collapse of drainpipes may occur even when using prescribed quality material. However, an inadequate design, inappropriate material quality and a lack of maintenance (high pressure flushing 1-2 times a year) may further limit the lifespan of the drainage system. Moreover, unless the main drain headers are located close enough $(<50 \mathrm{~m})$, "fish bone" type drain systems should be avoided, because they are difficult or impossible to clean. In addition maintenance of drainpipe is more complex in landfills constructed in a pit. Ceramic pipes, which were used in Germany in the 1980s, failed to resist and were found to be unstable and partly collapse, hampering or preventing the removal of incrustations and loosing its functionality. HDPE pipes may become brittle/deformed after decades of emplacement, and this may occur also to HDPE liners (Löwe, 2016). As a result, also in order to meet the legal requirements, drainpipes will need to be repaired or replaced, a very costly task, the result of which may be far from desirable. The same 
methods used in the repair of sewage pipes have also been applied in the remediation of landfill drainpipes. One procedure envisages a relining process obtained by placing new pipes inside collapsed ones (a frequently impossible task). Other methods involve digging down to the bottom of the landfill and substituting pipes. The burst-lining technology may also be applied, in which a new pipe is pressed from one manhole to another. In some cases $3-5 \mathrm{~m}$ diameter manholes have to be constructed in 30-40 high landfills, always respecting the strict work safety procedures. All these procedures are very expensive and even if pipe functionality is restored, the drainage system surrounding the pipe may remain clogged from incrustations.

- Construction of large diameter concrete vertical leachate collection shafts throughout the waste mass, which in views of the authors should be avoided, may be subject to strong deformation, rupture, and impossibility to carry out inspections.

The critical aspects listed above unfailingly contribute to the formation of high water tables (which may, dependent on landfill height under Mid-European climate conditions, reach levels of between around 10 to $15 \mathrm{~m}$ ). Water storage may also be layered water in landfills. In particular, in line with an increase in landfill height $(>15-20 \mathrm{~m})$, pressure exerted on the waste and accordingly density decreases in the lower part of the landfill. In addition in the lower part of a landfill gas competes with water in the waste pores, which results in a further decrease of the permeability of the waste mass (may be 1-2 orders of magnitude or even more), resulting in a number of serious issues (Figure 4):

- Due to the weight of the overlying waste and water-saturated pores of the waste material, water overpressure may build up. This situation results in lower friction values of the landfilled waste and consequent reduced mechanical stability. Therefore pore water pressures should be monitored and - if necessary - appropriate measures taken (e.g. dams at the foot of landfills, redu- ced slopes, water level reduction). This is particularly important for landfills in areas with high precipitation rates and/or in cases when landfilled wastes are characterised by relatively high moisture content. Due to a lower pore volume and relatively high sorption capacity, MBT landfills may need to be especially carefully monitored.

- A rise of the water table may increase the rate of leachate migration through a mineral clay layer placed at the bottom of the landfill, which does not provide complete impermeability.

- A regular distribution of the negative pressure values for gas extraction can be hampered and positive pressure values might originate causing uncontrolled gas and odours emissions;

- Limited circulation of gas (biogas under anaerobic conditions, air under aerobic conditions).

- Uncontrolled discharge of leachate.

- To extract the leachate and reduce elevated water tables, as well as in cases in which the drainage system fails to function adequately, vertical wells should be drilled to the bottom of the landfill and the leachate pumped out (Figure 5).

\subsection{In-situ treatment (Landfill Bioreactors)}

The role of this type of barrier is often completely neglected both from a regulatory and design viewpoint:

- The possibility of regulating the presence of water to be used in biodegradation is frequently overlooked, with leachate recirculation being prohibited by the authorities.

- There is a lack of cultural openness to the use of insitu waste treatment systems (in-situ aeration, semiaerobic landfill, etc.), largely due to the perception that the effectiveness of this technology has not been well demonstrated, although this technology is practiced in several countries since many years and has proven its applicability and success (Ritzkowsli and Stegmann, 2018).

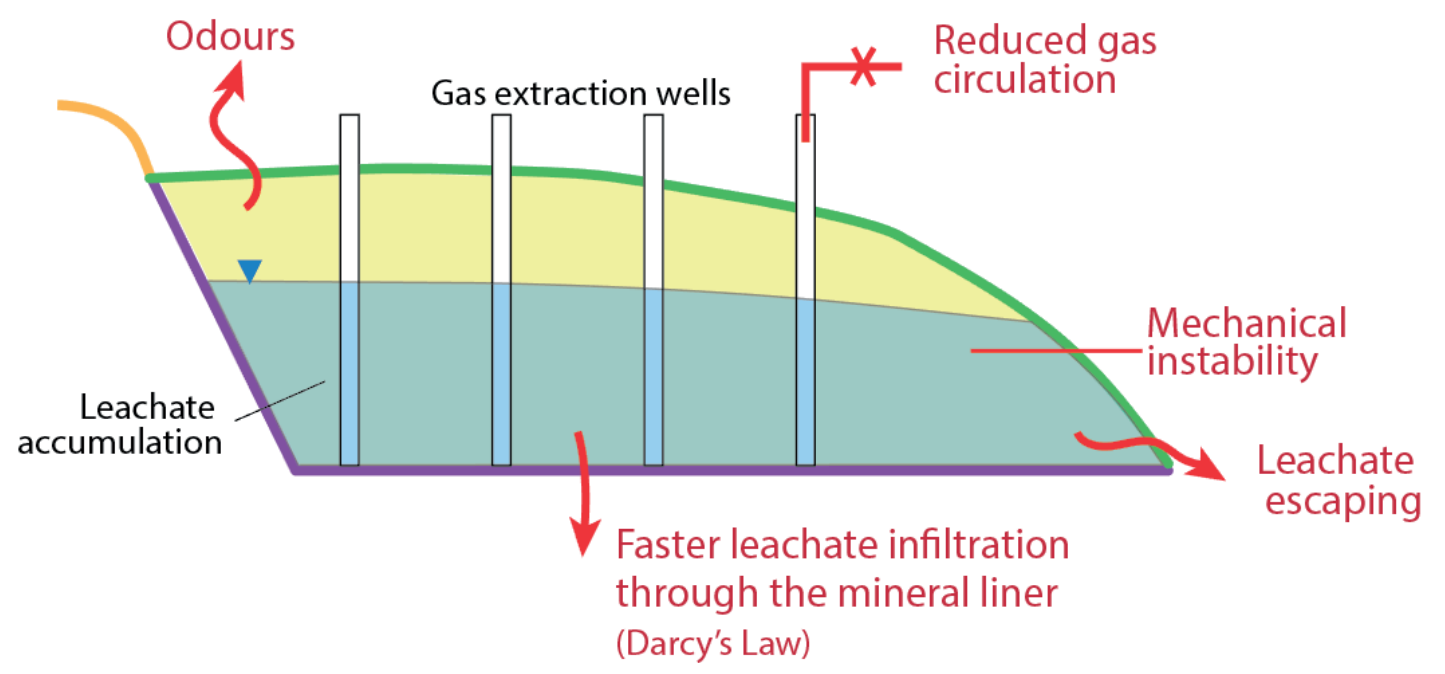

FIGURE 4: Graphical illustration of the main issues associated with the build-up of high water table in landfill, (modified from Cossu et al., 2020c). 


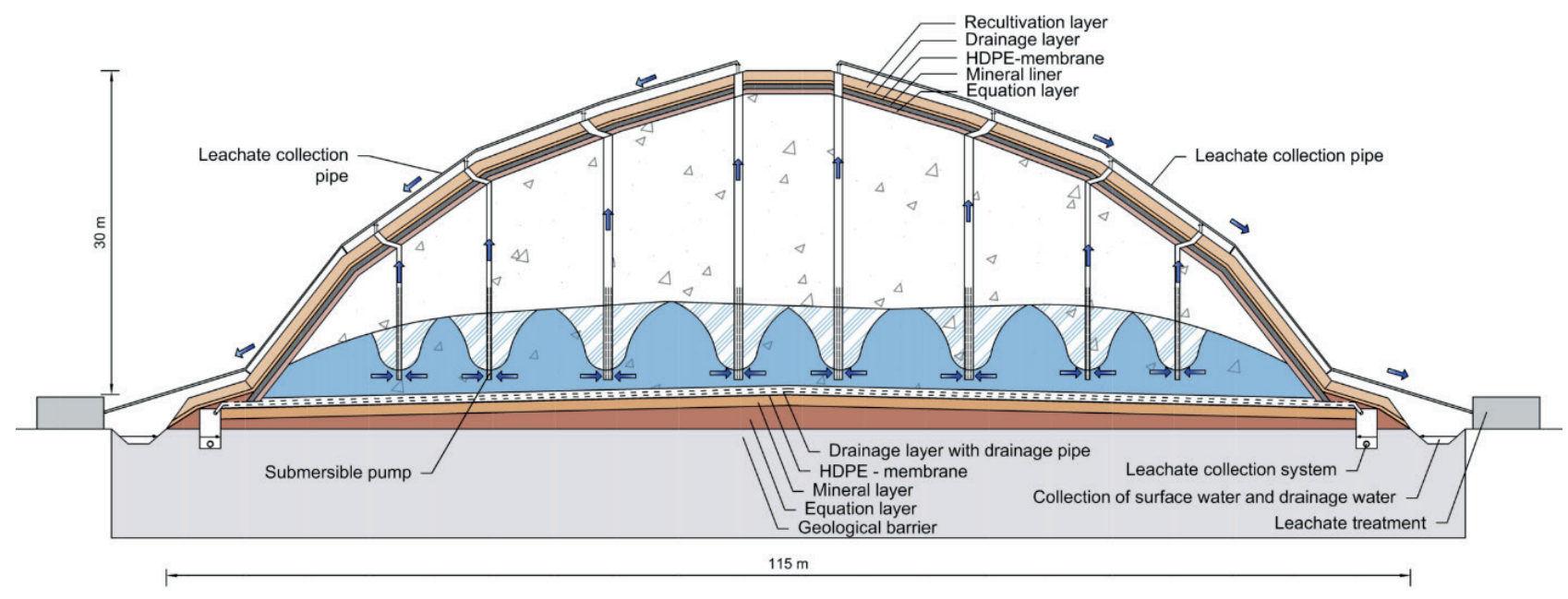

FIGURE 5: Lowering water table by means of vertical wells with submersible pumps.

- Scarce attention paid to the quality of materials used for daily cover, which in some countries is also applied for aesthetical reasons. In particular, the use of soil with low permeability should be avoided. In Germany on most landfills no daily cover is used due to the immediate high compaction of the incoming waste by heavy weight compactors.

- Relatively high temperatures (in some cases $>65^{\circ} \mathrm{C}$ ) observed in several high/deep landfills is another phenomenon that needs to be better addressed and investigated. In the opinion of the authors these occur typically due to the production of microbiological heat and low heat transfer in the waste (low water flux and significant insulation capacity of the landfilled waste). The high temperature, shift of $\mathrm{NH} 4+$ to $\mathrm{NH} 3$ (a highly toxic gas, toxicity limit around $150 \mathrm{mg} / \mathrm{L}$ free NH3) and the accumulation of organic acids due to low water flux may result in the inhibition of methanogenic bacteria and production of highly concentrated leachate. In addition chemical processes may also be responsible. High temperatures may also affect stability of the plastic liners and pipes.

- No final storage quality (FSQ) which is compatible with the environment and on which to base ad hoc projects and initiatives is defined for the landfill.

\subsection{Top cover}

The flexible role carried out by a final cover, based on both the type of landfill and quality of landfilled waste, with an aim to achieving environmental sustainability, is completely neglected. European legislation enforced throughout a series of countries establishes the need for landfills or landfill sections to be immediately capped once they have been filled to their final height. As a result, the emission potential of the landfill will be preserved (resulting in the so called dry tomb landfill, Stegmann, 1993). However, in view of the fact that surface liners may not remain effective indefinitely, emissions from the landfilled waste may occur once landfill operations are no longer monitored. This concept may only be applied to landfills where non-bi- ological degradable waste alone is landfilled (e.g. different kinds of inert waste and hazardous and industrial wastes). In the case of wastes containing degradable compounds (MSW), water content and, accordingly, water infiltration through the top cover should be controlled with the aim of promoting degradation of organic substances.

Another aspect that is frequently overlooked is related to the potential effects that surface covering of the landfill may produce on the oxidation of residual biogas emissions (small quantities and low methane concentrations). Such top layers of fractions should consist of composted material e.g. deriving from separate collection and treated by means of active biological stabilisation. Indeed, by including zones of bio-oxidising material (compost, wood shavings, etc.) in the cover structure, methane can be oxidised and contaminants such as Chlorofluorocarbons (CFC) present in the gas, degraded (Kjeldsen and Scheutz, 2018).

\subsection{Lining}

The main role in controlling landfill emissions has long been attributed to the lining system, although this does not guarantee a perfect and eternal insulation of the landfill from the surrounding environment.

If geomembranes are applied, lesions may potentially be manifested even during installation due to faulty welding. In addition to damage and breakages may occur during the management phase due to inadequate mechanical protection. Likewise, when using mineral materials, the creation of a layer that complies fully with the established legal requirements is not easy to achieve. In addition to an initial high quality material, rules of good geotechnical practice should be adhered to (compaction, dimensions of layers, type of compaction, humidity, controlled presence of granular material, etc.) and appropriate monitoring of both the bottom liner and frequently neglected slopes. In the latter case moreover, care should be taken to avoid degradation caused by atmospheric agents (erosion, drying, cracking, etc.). The latter aspects are frequently overlooked, thus resulting in potential dysfunctions and problems that are only detected subsequently. On the other hand, clay liners 
do not provide total permeability, but rather theoretically ( $1 \mathrm{~m}$ hydraulic head, homogeneous layer, water as leaching liquid) a $1 \mathrm{~m}$ layer of clay with a permeability $\mathrm{k}=10-9 \mathrm{~m} / \mathrm{s}$ (typically prescribed by legislation), will expedite (Darcy's Law) the passage of liquid over a time frame of little more than thirty years. The actual timings involved have however been shortened even further in the presence of leachate rather than water, in addition to the other critical factors highlighted (faulty installation, environmental degradation, etc.) (Cancelli et al., 1994).

The limited duration of the physical barriers should therefore be taken into account during the design stage in order to allow appropriate measures to be implemented. Should the ability of these barriers to contain emissions not be perpetual then it should be ensured by means of pretreatment and/or in-situ aeration that non acceptable emissions do not last longer than the lifetime of the physical barriers.

\subsection{Environmental barrier}

The environmental barrier (siting, morphology of the landfill, attenuation capacity of the unsaturated ground and water tables) is frequently overlooked during the design stage, although it is frequently revisited following the occurrence of cases of pollution.

Although lining systems are mandatory (Stief, 1989), appropriate landfill siting is also essential and may reduce the environmental impact of a landfill significantly. Areas having low permeability subsoil, where surface water is unable to enter the landfill and the ground water table is either very low and/or the quality of the water is too poor to use as drinking water (e.g. high natural salt content) are preferable for siting of a landfill.

Landfill morphology may negatively affect the efficiency of the drainage system; for this reason, morphologies envisaging deposition only above ground level are to be preferred. Landfills should be constructed as mounds in order to control leachate in the long-term, particularly following closure: leachate drainage systems can thus be better maintained and leachate runoff from the landfill will occur by gravity; conversely if landfills are constructed in pits, leachate will need to be persistently pumped from the bottom of the landfill. Moreover, waste deposition above ground level provides the advantage of a greater distance between the bottom of the landfill and the groundwater tables, also facilitating intervention when needed (maintenance, "landfill mining", etc.). Landfills should not be located in a valley, as in this case existing watercourses are often piped and waste is landfilled on top of these pipes. Pipes may subsequently become subject to leakage and the watercourse will be polluted by leachate (Cate, F.M., 1993). When landfills are built in mountainous areas on a mountain slope, a well-designed water control system (drainage system) should be installed between the mountain and the landfill, and unpolluted water transported separately out of the landfill site.

Aspects relating to the architectural design and economic planning of a landfill will impinge considerably on its environmental sustainability. Often a functional planning and designing of a landfill based on intended after use and insertion into the landscape is missing. Due to the wish to conceal view of the landfill, and the availability of gravel or mining pits may result in the construction of landfills below ground level and an ugly and scarcely functional aesthetics. Landfill should not be viewed as the final use of a specific area, but rather as an architectural structure intended to provide a series of functions geared to life of the community.

\section{NEW LANDFILL CONCEPT}

In order to better control long-term functionality of the installations, to ensure long term effective emission control and to avoid/reduce the above described landfill problems, landfills should be constructed and operated in a modified way. As a way to deal with many of these challenges the installation of horizontal layers with slopes to the outside of a landfill mound is proposed (Stegmann, 2017b). These layers should consist of inert coarse material at different levels of the landfill and should be constructed during landfill operation (Figure 6). The layers should be placed at vertical distances of approx. every $3 \mathrm{~m}$ in the lower part of a landfill (up to a height of about 12-15 m), and subsequently - when the permeability is somewhat higher - every $5 \mathrm{~m}$. If high water content waste is landfilled the coarse layers may be installed every $3 \mathrm{~m}$ throughout the entire landfill height (e.g. situation in countries with a very high content of putrescible waste). These layers should be approx. $30-50 \mathrm{~cm}$ thick and consist of coarse carbonate "free" material - preferably with a largely homogenous grain size (about $\pm 30 \mathrm{~mm}$ ); the material should be free of fines in order to avoid clogging and readily allow water and gas movement. Drainpipes perforated at their upper part may be installed to support leachate run-off and for monitoring. Once these layers have been installed, the amount of daily cover may be reduced and the horizontal layers used for multiple purposes:

- to avoid/significantly reduce water build-up in the landfill

- to allow better compaction and operation of high moisture containing waste

- to increase mechanical stability (higher friction angle)

- to allow gas extraction at an early stage during operation, avoiding significant climate gas emissions (about $20-30 \%$ of the total gas production potential), and by these means increase energy production.

- to be used - once gas utilization is no longer possible/ feasible - for in-situ aeration and later for passive aeration to maintain the landfill under high aerobic conditions

- to reduce the build-up of high temperatures and inhibition of methane production due to the reduction of pore water pressures and water storage

- to reduce clogging of the base drainage layer due to more homogeneous temperatures and allow precipitation in the upper drainage layers

Positive experiences have been gained using horizontal sand layers from a landfill filled with dredged material from Hamburg harbour. In addition horizontal drain layers were 


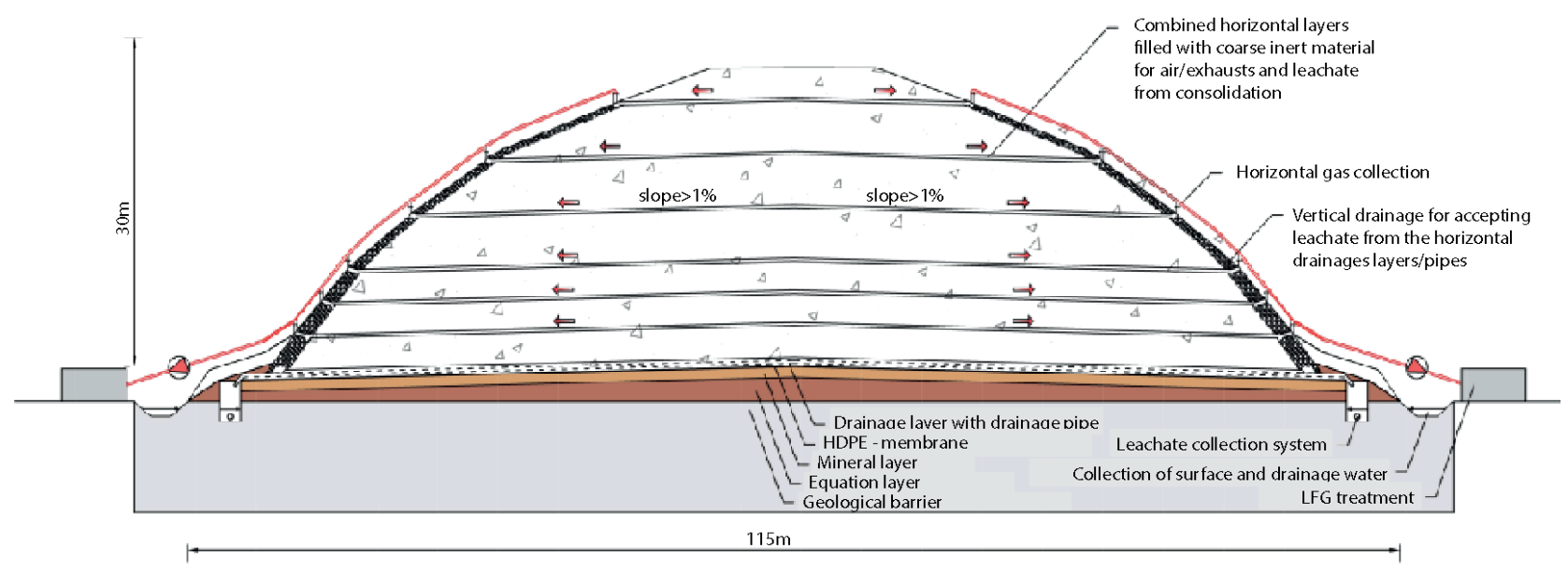

FIGURE 6: Modified landfill concept with multi-purpose horizontal layers of coarse material (Stegmann, 2017).

installed in a MBT waste landfill in Lower Saxony, Germany.

By developing an appropriate design for the base drainage system, water should be able to freely discharge from the bottom drain gravel layers of the landfill even in the presence of clogged or damaged drainage collection pipes. Frequent drainpipe inspection and cleaning should be ensured.

\section{CONCLUSIONS}

Landfill should be designed and constructed in line with the principle of environmental sustainability, in order to achieve over a period of less than one generation, a landfill with a low emission potential. Based on the multibarrier concept, technical measures aimed at controlling emissions and risk of contamination, in both the short and the long term, may include: minimization of contaminant mass introduced into the landfill, appropriate waste pre-treatment and in-situ treatments to minimize the emission potential of wastes, appropriate biogas and leachate collection systems, flexible use of the top cover, lining and appropriate landfill siting and morphology. However, landfill is typically deemed an obsolete and potentially redundant system and from a political, legislative and technical viewpoint it is frequently denied the attention devoted to other engineering works, lacking adequate financial investment to cover the costs required to ensure a sustainable landfill system. The lack of an appropriate landfill design project corresponding to the principles of sustainability based on use of the above-mentioned technical strategies, has resulted in a series of critical aspects in traditional non-sustainable landfills, which required specific technical solutions with a focus on ensuring landfill sustainability:

- Appropriate design of in-situ aeration, moistening and pre-treatment of waste, having consideration for the specific quality of the residues from the Circular Economy, which might accumulate contaminants during the recycling process.

- Use of proper granular drainage material to extend its long-term functionality and use of horizontal drainage layers at different levels of the landfill to avoid the bu- ilding up of high water table and assure the freely discharge of water even in the presence of clogged or damaged drainage collection pipes.

- Use of morphologies envisaging deposition only above ground level.

- Exploitation of the flexible role carried out by a final cover, based on both the type of landfill and quality of landfilled waste.

- Use of bio-oxidising material in the top cover of the landfill to oxidize residual biogas emissions.

- Consider the limited duration of the physical barriers already during the design stage in order to take appropriate measures to ensure that emissions polluting the environment do not last longer than the lifetime of the physical barriers.

- Appropriate selection of the siting and morphology of the landfill, considering the attenuation capacity of the unsaturated ground and water tables.

- Consider landfills for appropriate after-use

A modified concept for landfilling of raw and pre-treated waste is presented in order to avoid a lot of problems that landfills with increasing age will face.

\section{REFERENCES}

Allgaier, G., Stegmann, R., 2002. Evaluierung von Altdeponien im standardisierten Verfahren, Ergebnisse aus dem EU-Projekt EVAPASSOLD. In Hamburger Berichte 18, Deponietechnik 2002 (Hrsg.: R. Stegmann, G. Rettenberger, W. Bidlingmaier, H.-J. Ehrig) Verlag Abfall aktuell, Stuttgart, 329-354.

Andreola F., Barbieri L., Lancellotti I., Leonelli C., 2017. La valorizzazione dei rifiuti industriali inorganici. Ecoscienza, n. 2 , 26-27.

Brune, M., Ramke, H.G., Collins, H.-J., Hanert, H.-H., 1991. Instruction Processes in Drainage Systems of Sanitary Landfills. In: SARDINIA 91, 3rd International Landfill Symposium, Poceedings, Vol. II, pp. 999-1035. CISA, Via Marengo 34, 09123 Cagliari, Italy.

Cancelli, A., Cossu, R., Malpei, F., Offredi, A., 1994. Effects of leachate on the permeability of sand-bentonite mixtures. In: Christensen, T.H., Cossu, R., Stegmann, R. (Eds.), Effect of Organic Liquids on the Hydraulic Conductivity of Natural Clays, in Landfilling of Waste: Barriers. E \& FN Spon, London, pp. 259-293. ISBN 0-419-15990-8.

Cate, F.M., 1993. Landfill Siting Criteria developed in Central Lower Austria, In: SARDINIA, 1993, Proceedings, 4. International Waste Management and Landfill Symposium, CISA, Contact: EuroWaste Srl, Padova, Italy. 
Cossu R., Grossule V., 2018. Landfill bioreactors. In: Cossu, R., Stegmann, R., 2018. Solid waste landfilling: Concepts, processes, technologies. Chapter 14.3, 831-844. Elsevier Publisher, ISBN: 978-0128183366.

Cossu, R. and Pivato, A., 2018. Aftercare completion: Final storage quality assessment. In: Cossu R., Stegmann R., Solid Waste Landfilling. Concepts, Processes, technologies, Chapter 16.1, 887-899. Elsevier, ISBN 978-0-12-8183366.

Cossu, R., 2012. The environmentally sustainable geological repository: the modern role of landfilling. Waste Management 32, 243-244.

Cossu, R., 2016, Back to Earth Sites: From "nasty and unsightly" landfilling to final sink and geological repository. Waste Management 55, 1-2, doi: 10.1016/j.wasman.2016.07.028

Cossu, R., 2018. Multibarrier principles in landfilling. In: Cossu R., Stegmann R., Solid Waste Landfilling. Concepts, Processes, technologies, Chapter 2.1, 229-246. Elsevier, ISBN 978-0-12-8183366.

Cossu, R., Grossule, V., Lavagnolo, M.C., 2020a. Qualità finale della discarica sostenibile e chiusura della post gestione. In: La discarica sostenibile: Ruolo nell'Economia Circolare e proposte normative. Cap. 6, pagg. 141-156. CISA publisher, ISBN: 9788862650182.

Cossu, R., Grossule, V., Lavagnolo, M.C., 2020b. What about residues from circular economy and role of landfilling? Detritus Journal, Volume 09 - 2020 / pages 1-3. doi.org/10.31025/2611$4135 / 2020.13920$

Cossu, R., Grossule, V., Lavagnolo, M.C., 2020c. II reattore discarica: barriere, loro evoluzione e attuali criticità. In: La discarica sostenibile: Ruolo nell'Economia Circolare e proposte normative. Cap. 3.5, pagg. 61-90. CISA publisher, ISBN: 9788862650182.

Cossu, R., Grossule, V., Lavagnolo, M.C., 2020d. Linee guida della regione Lombardia per la discarica sostenibile. In: La discarica sostenibile: Ruolo nell'Economia Circolare e proposte normative. Cap. 10, pagg. 219-237. CISA publisher, ISBN: 9788862650182.

Cossu, R., Stegmann, R. 2019. Solid Waste Landfilling, Concepts, Processes, Technology. Elsevier, 2018, ISBN: 9780128183366.

Delibera Giunta Regionale 7 Oct 2014, no 2461 (D.G.R. 2461/14). Linee guida per la progettazione e gestione sostenibile delle discariche.

GeoSyntec Consultants, Inc, 2003. Landfill Facility Compliance Study Task 7 Report Study of Emerging Technologies in Waste Management for MSW Landfills. Walnut Creek, California.

Grossule, V., Lavagnolo, M.C., 2019. Lab tests on semi-aerobic landfilling of MSW under varying conditions of water availability and putrescible waste content. Journal of Environmental Management, 256. DOI: 10.1016/j.jenvman.2019.109995

Grossule, V., Morello, L., Cossu, R., Lavagnolo, M.C., 2018. Bioreactor Landfills: comparison and kinetics of the different systems. Detritus, 03, 100-113.

Heimovaara $T$, Cossu $R$, van der Sloot $H_{1}, 2014$. State of the art and perspectives for sustainable landfills. In: Cossu R., van der Sloot H., 2014. Sustainable landfilling. Cap. 1, 19-44. CISA Publisher, ISBN: 978-88-6265-005-2.

Heyer, K.U., 2018. Capital and operational costs. In Cossu, R., Stegmann, R. Solid Waste Landfilling. Concepts, Processes, technologies, Chapter 21.1, 1109-1124. Elsevier, ISBN 978-0-12-8183366.

Heyer, K.U., Hupe, K. and Stegmann, R. (2013), Landfill Gas Emissions from the Disposal of mechanically-biologically pre-treated Waste, SARDINIA, 2013, Proceedings, 14. International Waste Management and Landfill Symposium, CISA, Contact: EuroWaste Srl, Padova, Italy

Heyer, K.U., Stegmann,R. (2005), The long term behaviour and emission potential of landfills, SARDINIA, 2005, Proceedings, 5. International Waste Management and Landfill Symposium, CISA, Contact: EuroWaste Srl, Padova, Italy

Hupe, K.U., Stegmann, R. (2013): Landfill Aeration as a Contribution to Climate Protection: Developments and Experience. In: SARDINIA, 2013, Proceedings, 14. International Waste Management and Landfill Symposium, CISA, Contact: EuroWaste Srl,Padova, Italy.

Kjeldsen, P, Scheutz C., 2018. Landfill gas management by methane oxidation. In: Cossu R., Stegmann R., Solid Waste Landfilling. Concepts, Processes, technologies, Chapter 9.5, 477-497. Elsevier, ISBN 978-0-12-8183366.

Lavagnolo, M.C. and Grossule, V., 2018. From 3R to 3S: An appropriate strategy for Developing Countries. Detritus, Volume 04, 1-3. DOI:10.31025/2611-4135/2018.13749

Lavagnolo, M.C., Grossule, V., Raga, R., 2018. Innovative dual-step management of semi-aerobic landfill in a tropical climate. Waste Management, 1-10. DOI:10.1016/j.wasman.2018.01.017
Leikam, K., Stegmann, R., 1999. Influence of mechanical-biological pretreatment of municipal solid waste on landfill behaviour. Waste Management and research, 17, 424-429. ISSN 0734-242X

Löwe, D. (2016), Sanierung von Sickerwasserfassungssystemen, from Stegmann, Rettenberger, Ritzkowski, Kuchta, Siechau, Heyer, Eds. Deponietechnik 2016, Verlag Abfall Aktuell, ISBN 978-3-98175723-1

Matsufuji, Y., Tanaka, A., Cossu, R., 2018. Semiaerobic landfilling. In Cossu, R., Stegmann, R. Solid Waste Landfilling, Concepts, Processes, Technology. Chapter 14.2, 807-830. Elsevier, 2018, ISBN: 9780128183366.

Pivnenko, K., Eriksson, E., Astrup, T.F., 2015. Waste paper for recycling: Overview and identification of potentially critical substances. Wastem Management, 45, 134-142, doi.org/10.1016/j.wasman.2015.02.028

Republic of Slovenia, Statistical office, 2017. https://www.stat.si/ StatWeb/en/News/Index/7761 (Accessed on 16th January 2020)

Ritzkowski, M., Heyer, K.-U., Stegmann, R. (2006) Fundamental Processes and implications during in situ aeration of old landfills. In: Waste Management 26, Volume 4, 356-372, Elsevier Ltd., ISSN 0956-053X

Ritzkowski, M., Stegmann, R., 2003. Emission behaviour of aerated landfills : results of laboratory scale investigations. In: Proceedings Sardinia 2003, Ninth International Waste Management and Landfill Symposium. S. Margherita di Pula, Cagliari, Italy; 6-10 October 2003

Ritzkowski, M., Stegmann, R., 2007. Controlling greenhouse gas emissions through landfill in situ aeration. International Journal of Greenhouse Gas Control 1, 281-288. https://doi.org/10.1016/S17505836(07)00029-1.

Ritzkowski, M., Stegmann, R., 2018. Landfill in situ aeration. In Cossu, R., Stegmann, R. Solid Waste Landfilling, Concepts, Processes, Technology. Chapter 16.2, 899-014. Elsevier, 2018, ISBN: 9780128183366 .

Ritzkowski,M., Stegmann,R., Walker,B, (2013): Methodological Approach to Reduce Aftercare at the Teuftal Landfill. In: SARDINIA, 2013, Proceedings, 14. International Waste Management and Landfill Symposium, CISA, Contact: EuroWaste Srl, Padova, Italy.

Sabbas, T., Polettini, A., Pomi, R., Astrup, T., Hjelmar, O., Mostbauer, P., Cappai, G., Magel, G., Salhofer, S., Speiser, C., Heuss-Assbichler, S., Klein, R., Lechner, P., 2003. Management of municipal solid waste incineration residues. Waste Management 23, 61-88.

Stegmann R., 2018. Mechanical biological pretreatment. In: Cossu, R., Stegmann, R., 2018. Solid waste landfilling: Concepts, processes, technologies. Chapter 4.1, 141-156. Elsevier, ISBN: 978 0128183366.

Stegmann, R. and Heyer, K.-U. (2001): Landfill concept for mechanicalbiologically treated residual waste. CISA (ed.) Proceedings of the Eighth International Landfill Symposium, pp. 381-388. CISA - Environmental Sanitary Engineering Centre, Cagliari, Italy.

Stegmann, R. and Heyer, K.-U., (2002): Konzept für eine nachsorgearme MBV-Deponie. In: Stegmann/Rettenberger/Bidlingmaier/Ehrig (Eds.), Deponietechnik 2002, Hamburger Berichte 18, Verlag Abfall akutell, Stuttgart.

Stegmann, R., 1993. Design and Management of a Dry Landfill System, In: SARDINIA, 1993, Proceedings, 4. International Waste Management and Landfill Symposium, CISA, Contact: EuroWaste Srl, Padova, Italy.

Stegmann, R., 1995. Concepts of Waste Landfilling. In: Christensen T.H., Cossu, R., Stegmann, R. (Eds.), SARDINIA 95, Vol. I, pp. 3-12. CISA, Via Marenago 34, 09123 Cagliari, Italy

Stegmann, R., 2017a. Development of waste management in the last 30 years, Sardinia, 2017 Proceedings of the 16. International Landfill Symposium, CISA - Environmental Sanitary Engineering Centre, Cagliari, Italy.

Stegmann, R., 2017b, Discussion of landfill problems and proposals for solutions, Sardinia 2017 Proceedings of the 16. International Landfill Symposium, CISA - Environmental Sanitary Engineering Centre, Cagliari, Italy.

Stegmann, R., Heyer, K.-U., Hupe, K. (2011): Do we have to take care of landfills forever? In: SARDINIA, 2011, Proceedings, 13. International Waste Management and Landfill Symposium, CISA, Contact: EuroWaste Srl, Padova, Italy. 
Stegmann, R., Heyer, K.-U., Hupe, K., Willand, A. (2006): Deponienachsorge : Handlungs-optionen, Dauer, Kosten und quantitative Kriterien für die Entlassung aus der Nachsorge, Umweltforschungsplan des Bundesministeriums für Umwelt, Naturschutz und Reaktorsicherheit. Abfallwirtschaft, Förderkennzeichen (UFOPLAN) 20434 327, im Auftrag des Umweltbundesamtes, 2006. see: http://www. umweltdaten.de/publikationen/fpdf-I/3128.pdf or: http://www. ifas-hamburg.de/pdf/UFOPLAN_IFAS.pdf
Stegmann, R., Heyer, K-U., Hupe, K., Ritzkowski, M., 2003, Discussion of criteria for the completion of landfill aftercare, Sardinia 2003 Proceedings of the 9. International Landfill Symposium, CISA - Environmental Sanitary Engineering Centre, Cagliari, Italy.

Stief, K. (1989), Multibarrier Concept in West- Germany In: T.H. Christensen, R. Cossu and R. Stegmann (Eds) : Sanitary Landfilling, Process, Technology and Environmental Impact, Academic Press. 